\title{
ANALYSIS OF REPAIRED GAS TURBINE AND COMPRESSOR BLADES
}

\author{
Alexander Tishkunov ${ }^{1}$, Sergejs Gluhihs ${ }^{2}$, Aleksandrs Korjakins, Andris Popovs \\ Institute of Materials and Structures of Riga Technical University, \\ Azenes st. 16-323, LV-1048, Riga, Latvia \\ E-mails: ${ }^{1}$ alex_ti@inbox.lv; ${ }^{2}$ s_gluhih@inbox.lv
}

Received 20 March 2008; accepted 31 March 2008

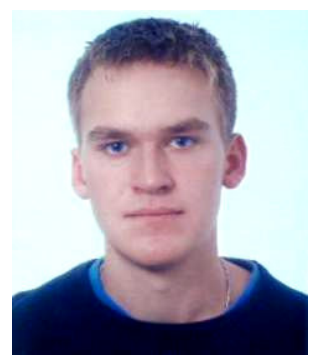

\section{Alexander TISHKUNOV}

Date, place of birth: 31.05.86; Riga, Latvia.

Education: 2nd course bachelor student of RTU (faculty of building and civil engineering).

Experience: 2006 - present - junior researcher, Institute of Materials and Structures, Riga Technical University. Field of research: strength of structures, computer analysis of structures.

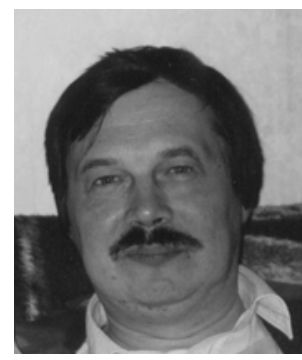

Sergejs GLUHIHS, Dr Sc eng

Date, place of birth: March 11, 1953, Riga.

Education: 1976 - St. Petersburg Technical University, $\mathrm{PhD}$ in mechanical engineering.

Experience: 1976 - present - Institute of Materials and Structures, Riga Technical University.

Publications: Author of more than forty different scientific publications.

Field of research: strength and dynamics of structures, damping analysis, mechanics of composite materials, numerical methods and computer analysis of structures, strength of foam-rubber.

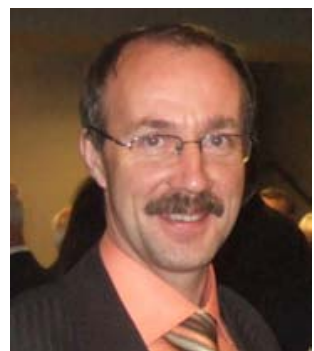

\section{Aleksandrs KORJAKINS}

Date, place of birth 29. 01.1963 in Jekabpils, Latvia.

Education: 1980-1985 - graduate student at Riga Technical University, Faculty of Architecture and Civil Engineering.1989-1992 - postgraduate student at Riga Technical University, specialty - Mechanics of Solids. Experience: 1985 - engineer at Riga Technical University; 1993 - researcher; 1999 - docent; 2002 - Assoc Prof; 2006 - Prof at Riga Technical University.

Publications: Author of more than fifty different scientific publications.

Field of research: Fracture toughness of composites, strength of structures, damping and dynamic analysis of constructions, numerical methods and computer analysis of structures.

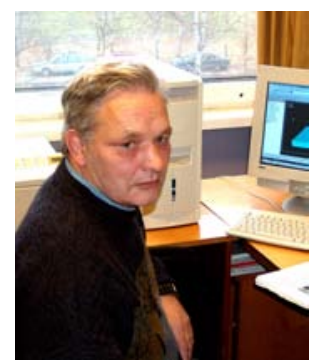

Andris POPOVS, Dr Sc Eng

Date, place of birth: 21.02.1944; Riga, Latvia.

Education: 1967 - Riga Aviation Institute (Faculty of Mechanics)

Experience: 1967-1999 - Riga Aviation Institute, Scientist.

1999 - present - Dr Sc Eng, Intsitute of Materials and Structures, Riga Technical University.

Field of research: fatigue and dinamics of structures, strength of structures, computer analysis of structures. 


\begin{abstract}
In order to reach desired levels of efficiency and power output of jet engines, advanced gas turbine and compressor blades made from Ti-6AL-4V alloy operate at very high temperatures (up to $600^{\circ} \mathrm{C}$ ) and speeds (up to $10000 \mathrm{rpm}$ ) [3-4]. Pressure of springing streams and inertial forces are main reasons of stress appearance in the blades. Besides that, blade usually could be out of action after one's edges had become damaged under temperature or foreign object hit negative influence. High cycle fatigue (HCF) accounts for $56 \%$ of major aircraft engine failures and ultimately limits the service life of most critical rotating components. Extensive inspection and maintenance programs have been developed to detect, renew and replace defected blades, to avoid catastrophic engine failure. Various modern technologies including laser cladding (filling layers of sprayed material) allow prolongation of blades' life by damaged part's renovation with alternate material. The general aim of the present work concludes of blades' mechanical bahavour comparison before and after renewal.
\end{abstract}

Keywords: turbine blade, compressor blade, modelling, streams, internal cooling, damage simulation, material change, Von Mises equivalent stress, displacements, experiment, result comparison.

\section{Introduction}

To solve the problem, separately have been researched two kinds of blades: compressor and turbine blades, which both are used as parts of differing aero jet engines (Figs 1, 2). On the occasion of that, the 3Dimension parametric models of mentioned blades were created by SolidWorks software foundation using scanned and measuring information.

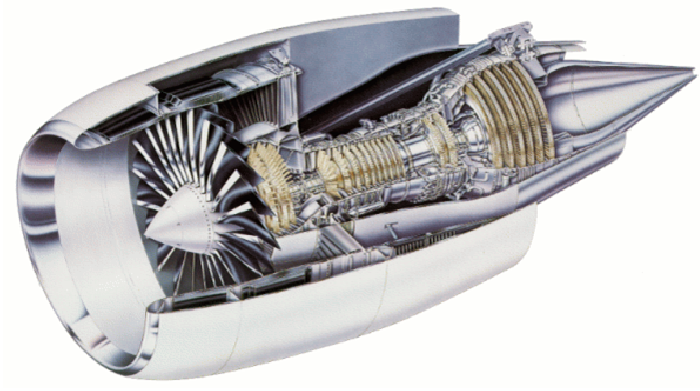

Fig 1. Turbine
analysis(FEM) Von Mises equivalent stresses and displacements for all overlooked models have been obtained.

\section{Preparing for calculation and the experi- ment}

To make certain about conformity of models and the original samples, the first calculation step included own frequency determination and their comparison with experimental results. An experimental frequency value responce had been received with the help of Polytec PSV400 laser vibrometer system before other analysis started. Its modular design allows the frequency, velocity and displacement capabilities to be tailored to specific or multiple applications. Both analogue and digital decoders are available, giving a frequency range from near DC to $20 \mathrm{MHz}$, with velocities to $\pm 10 \mathrm{~m} / \mathrm{s}$ and displacements from the sub-nanometer to meter range. A vibrometer system is comprised of controller electronics and a noncontact standard-optic or fiber-optic sensor head. The controller provides signals and power for the sensor head, and processes the vibration signals. These are
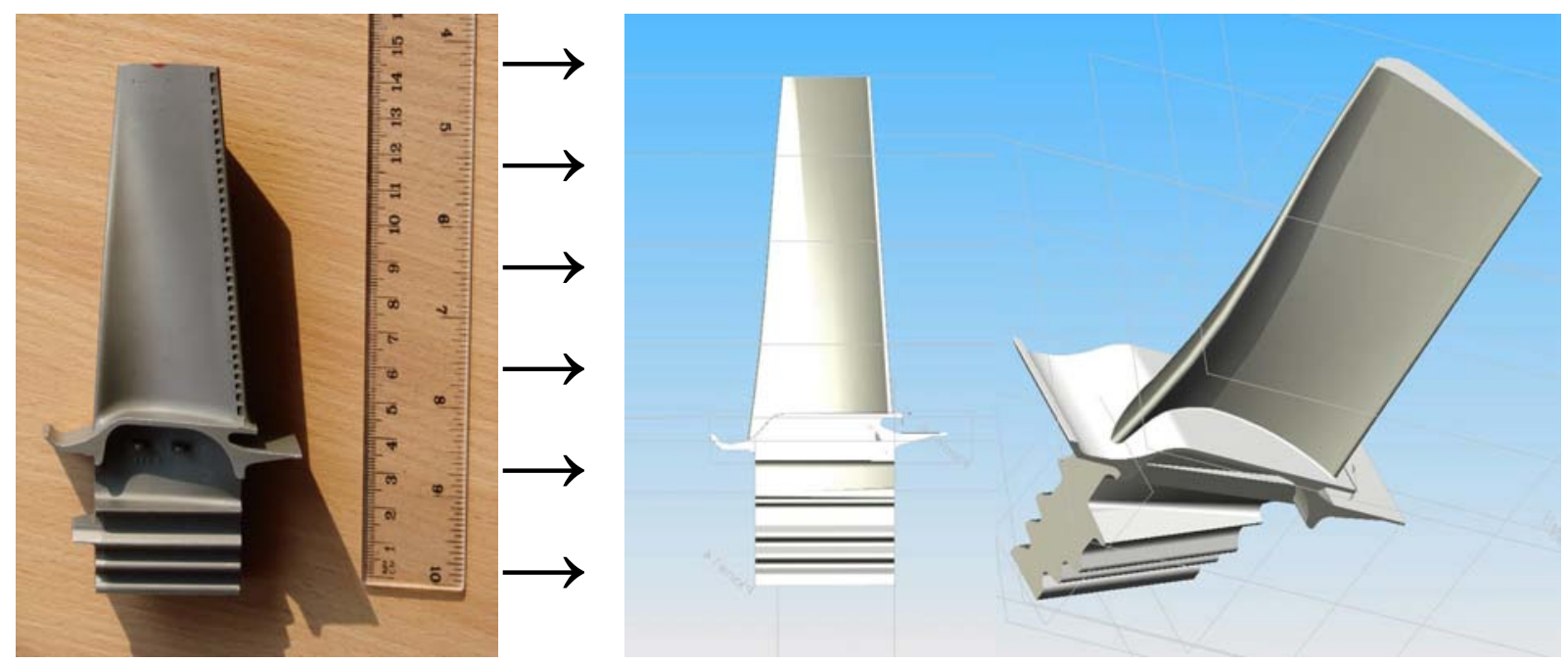

Fig 2. Turbine blade's modeling

Original sampled and renewed blades' mechanical behavour comparison consisted of stress-strain state analysis for origin and repaired damage-simulated blades using SolidWorks and it's integrated module CosmosWorks software [1]. As results of finite element electronically converted by specially developed decoders within the controller to obtain velocity and displacement information about the test structure. This information is provided by OFV-5000 in either analog or digital form, for further data evaluation. 
Data comparison of two most significant frequency values from experiment and Cosmos-Works calculations is shown in the figure 3 .

\begin{tabular}{|l|c|c|}
\hline \multicolumn{3}{|c|}{ Comparison table } \\
\hline Frequency Analitycal $(\mathrm{Hz})$ & 1968 & 3419 \\
\hline Frequency Experimental $(\mathrm{Hz})$ & 1945 & 3470 \\
\hline
\end{tabular}

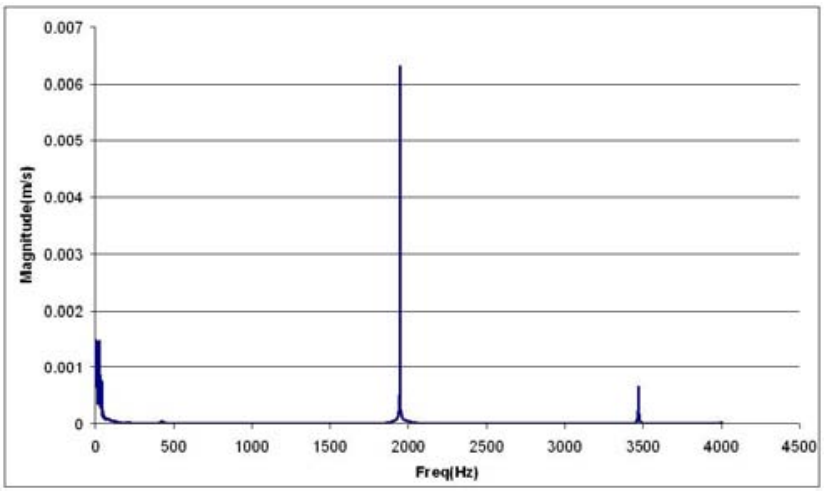

Fig 3. Frequency chart and value comparison table

The continuation of modeling was directed to possible blades' defects simulation [7]. Damaged side and upper edges for 5, 10, 15 millimeters and 5, 15, 30 millimeters accordingly, as also dents in frame were filled up with alternate material alloy - Inconel Alloy 718 [2]. Main differences between initial and welded alloys are focused on module of elasticity and thermal conductivity disparities are shown in the table [5-6]. Overlooked

Material properties

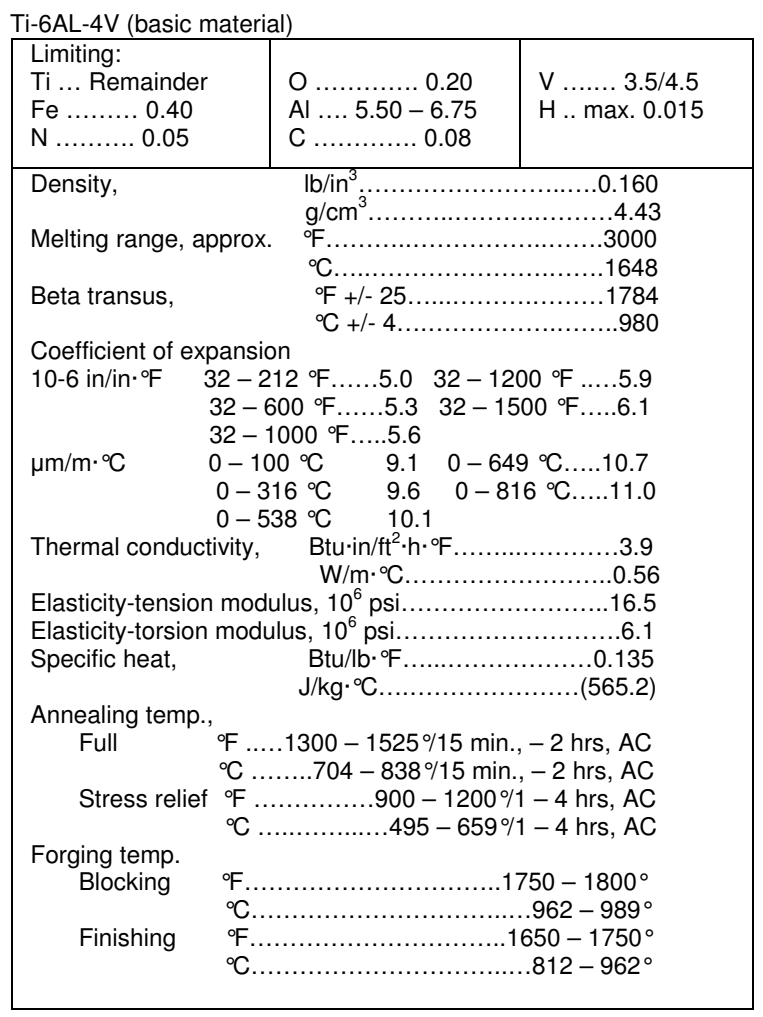

Table continued below

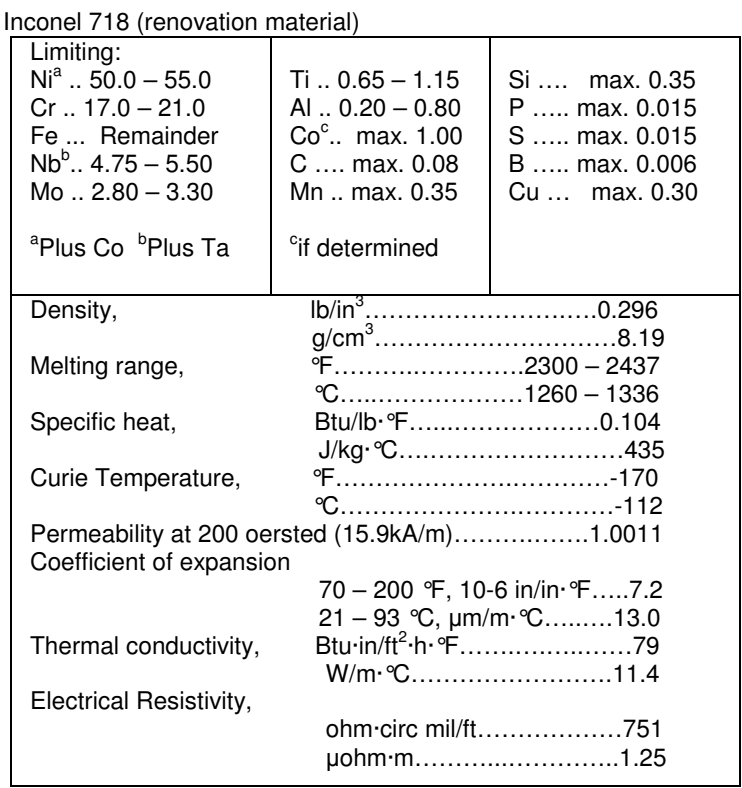

compressor and turbine blades are details of differing jet engines, so their parameter characteristics are differing too. Speed of springing stream $V_{\text {stream }}=256 \mathrm{~m} / \mathrm{s}$ over compressor blade is taken basing on known plane's flying speed. Temperature of this stream $\boldsymbol{T}_{\text {stream }}=\mathbf{- 5 0}{ }^{\circ} \boldsymbol{C}$ applied by flying altitude. Blade's rotating speed equals to $\mathbf{7 8}$ rounds per second (rps), while in turbine same parameter equals to 165 rps. Taking into consideration both external (gas from set on fire fuel mixure) and internal (cool air) streams over the rotating turbine blade, two additional parameters are applied for calculation: MassFlow = $0.001 \mathrm{~kg} / \mathrm{s}$ and pressure of cooling stream instead of it's speed $\boldsymbol{P}_{\text {stream }}=301.3 \mathrm{MPa}$. Temperatures of inner and outside streams are $20^{\circ} \boldsymbol{C}$ and $600^{\circ} \mathrm{C}$ accordingly.

\section{Stress-strain analysis}

Performed task implied consideration of an external air and gas laminar streams and their influence over the rotating blades, as well as taking in account internal turbo-blades cooling by flowing channels inside them. Applied thermal condition and flow rate data was passed by the integrated module of CosmosWorks software. Besides that, the interaction between blades' allowance in the turbine and compressor has been examined applying European standard by three blades, fixed in the rotor one by one. The middle blade was under primary attention. After all finite element models had been obtained, Von Mises equivalent stress determination got under way. Used Von Mises equivalent stress formula is brang lower, where $\tau$ is tangential strain in indicated planes:

$$
\sigma_{v M}=\frac{1}{\sqrt{2}} \sqrt{\left(\sigma_{x}-\sigma_{y}\right)^{2}+\left(\sigma_{y}-\sigma_{z}\right)^{2}+\left(\sigma_{z}-\sigma_{x}\right)^{2}+6 \tau_{y z}^{2}+6 \tau_{z x}^{2}+6 \tau_{x y}^{2}}
$$


General analysis of compressor blade was concentrated on three blades combination model, while turbine blade was looked over as single object [8]. Nondamage variant of compressor blades acquiring proper conditions (flow rate, temperature, loads) was examined first. Expected main stress concentration, as well as maximum stress value for whole researching model due tue great inertial forces appeared in the blades' bottom part, where blade's "wing" connects crown. That tendence was typical for all overlooked models.

The goal contained in material replacement influence over the stress value increase in object's volume, therefore were made results' gathering from the origin and replaced material part's border place.

Renewing side edge for $5 \mathrm{~mm}, \sigma_{\max }=320 \mathrm{Mpa}$ result was exceeded, for $10 \mathrm{~mm} \sigma_{\max }=485 \mathrm{Mpa}$ and for $15 \mathrm{~mm}$ $\sigma_{\max }=638 \mathrm{Mpa}$. From these integers, which were received from local plot, following dependence can be inferenced:

$$
\left(\left(\sigma_{\max (i)}-\sigma_{\max (i-1)}\right) / \sigma_{\max (i)}\right) \times 100 \%,
$$

when $\sigma_{\max (i)}$ is last made maximum stress calculation result, and $\sigma_{\max (i-1)}-$ previous maximum stress calculation result. $\mathrm{i}=2,3,4,5 \ldots \mathrm{n}$. The first value $\sigma_{\max }=179 \mathrm{Mpa}(\mathrm{i}$ $=1$ ) was concluded by non-damage research. In proceeding $\sigma_{\max (2)}>\sigma_{\max (1)}$ for $44 \%$,

$\sigma_{\max (3)}>\sigma_{\max (2)}$ for $34 \%, \sigma_{\max (4)}>\sigma_{\max (3)}$ for $24 \%$.

With reference to turbine blade, all analysis results may be seen in figure below (Fig 4):

Note: upper row corresponds non-damaged variant, lower - damaged side edge $(5 \mathrm{~mm})$ variant with putting on Inconel 718 alloy.

\section{$200^{\circ} \mathrm{C}$}

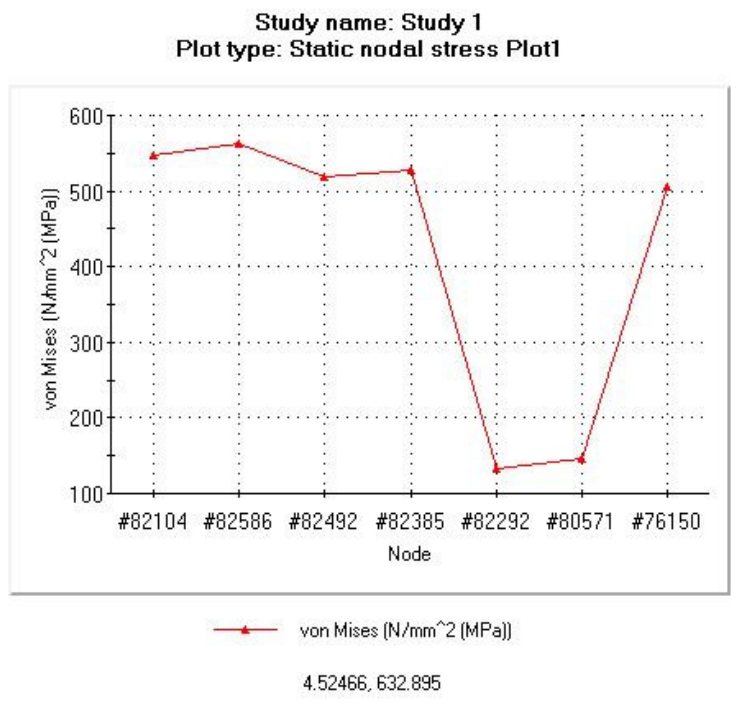

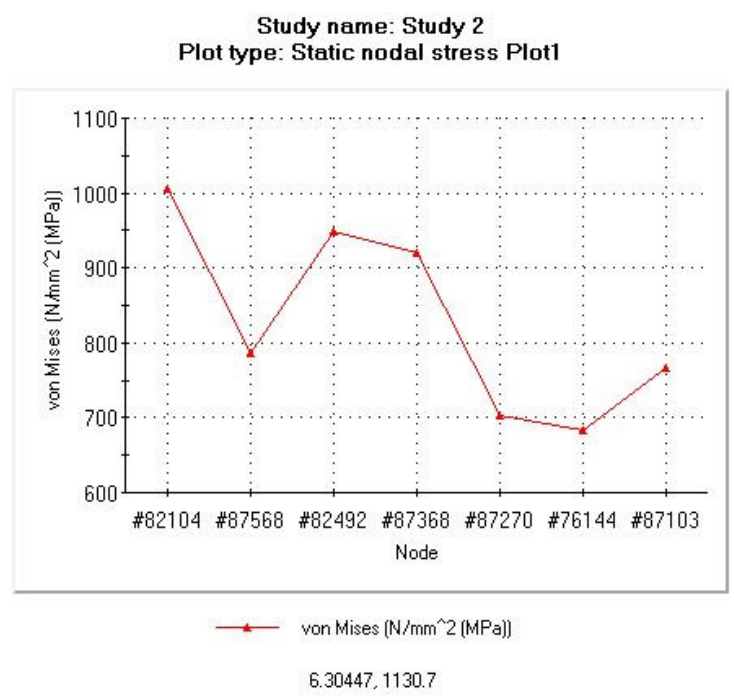

$700^{\circ} \mathrm{C}$
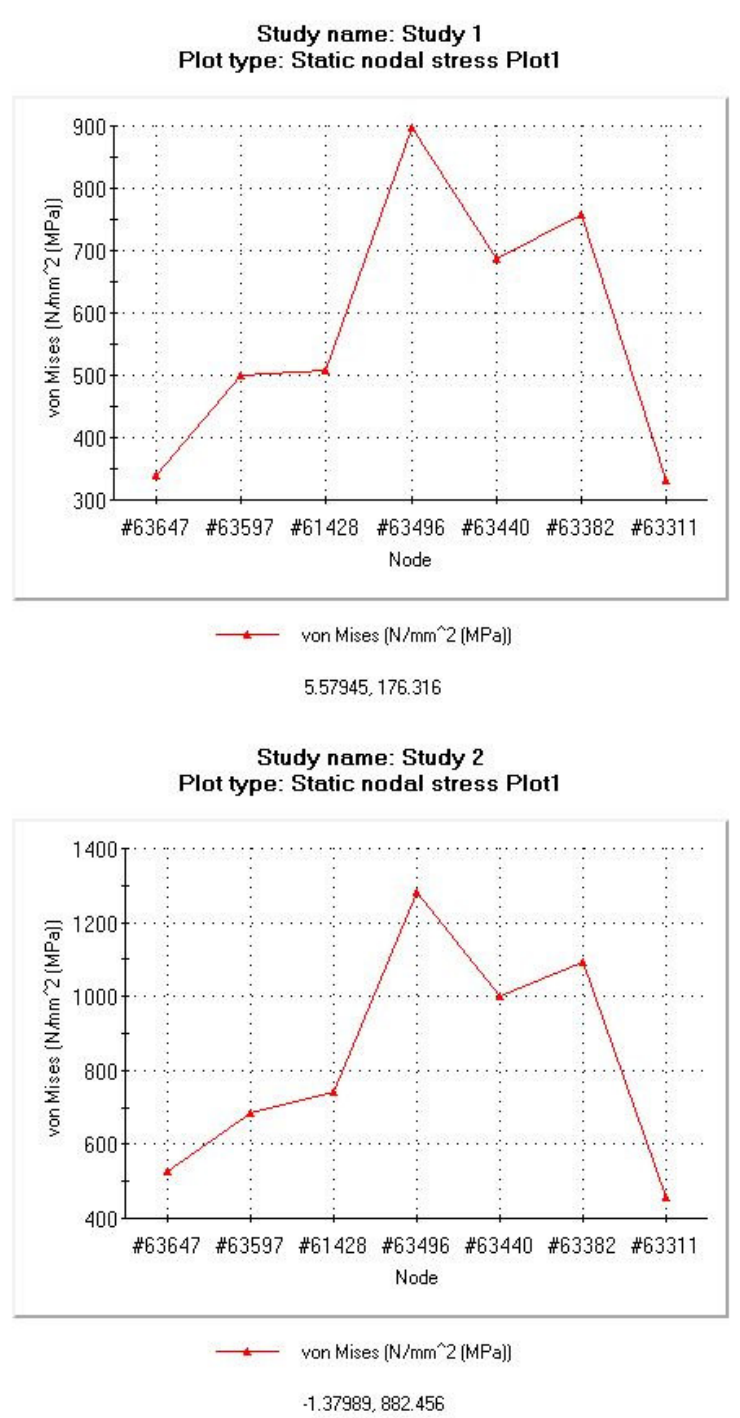

Fig 4. Stress analysis of turbine blade 


\section{Conclusions}

So as to get optimal power output of jet engine, all compressor and turbine blades have to be trig and function properly. From the economical point of view, to renew damaged blades is much favourable than to replace them by new ones. This work' s general aim was to compare differences between original and renewed objects' equivalent Von Mises stress - strain values, which appear in the blades at the same working conditions. From reached results following pattern can be concluded:as bigger damage is repaired and accordingly more alternate material (with bigger specific gravity and thermal ex-pansion) is placed in the object, as larger stress values are got in the result.

\section{Acknowledgement}

The financial support of European Commission within the 6th Framework Program Strategic Targeted Research Project FANTASIA: Flexible and near-netshape generative manufacturing chains and repair techniques for complex shaped aero engine parts Contract No.: AST5-CT-2006-030855.

\section{References}

1. COSMOS Works. Online User's Guide Structural Research and Analysis Corporation. USA, 2004.
2. Costa, M. Y. P.; Voorwald, H. J. C.; Pigatin, W.L. et al. 2006. Evaluation of shot preening on the fatigue strength of anodised Ti-6Al-4V Alloy. In Material Research, vol. 9, no. 1.

3. Drive, M. Cad to metal arcam AB. Arcam Ti-6Al-4V Eli titanium alloy: extra low interstitials enchanse material properties.

4. Jayaraman, N.; Prevey, P.S.; Ravindranath, R. 2005.Improved damage tolerance of Ti-6Al-4V aero engine blades and vanes using residual compression by design.

5. Sakuma, A.; Matsuura, T.; Suzuki, T. et al. 2006. Upgrading and life extension technologies for geothermal steam turbines. In JSME International Journal, Series B, vol. 49, no 2.

6. Sakuma, A.; Takahashi, T.; Watanabe, O. et al. 2000. Upgrading and life extension technologies for geothermal steam turbines. In: Proceedings of World Geothermal Congress, Kyushu - Tohoku, Japan, May 28 - June 10, 2000.

7. Xu, C.; Chen, W. J. 2005. Computational analysis on a compressor blade. In: Int. Conf. On Jets Wakes and Separated Flows, ICJWSF-2005, October 5-8, 2005, Toba-shi, Mie, Japan.

8. Ивасишин, О. М.; Саввакин, Д. Г.; Бондарева, К. А. и др. 2005. Производство титановых сплавов и деталей экономичным метедом порошковой металлургии для широкомасштабного промышленного применения.

\section{SUREMONTUOTOS DUJŲ TURBINOS IR KOMPRESORIAUS MENČIŲ ANALIZĖ}

A. Tishkunov, S. Gluhihs, A. Korjakins, A. Popovs

S a n trauka

Šiame darbe aprašoma, kaip buvo atliekama suremontuotų turbinos ir kompresoriaus menčiu atsparumo analizė. Svarbiausia buvo palyginti ekvivalentiniu ịtampų rezultatus iki ir po menčiu renovavimo alternatyvia medžiaga. Modelių, kurie buvo suprojektuoti kompiuterine programa SolidWorks, medžiaga buvo keičiama tose darbinès mentės briaunos vietose, kur buvo galimi eksploataciniai defektai.

Reikšminiai žodžiai: turbinos mentè, kompresoriaus mentè, modeliavimas, srautai, vidinis vėdinimas, nuostolių simuliavimas, medžiagų pakitimas, Von Mise ekvivalentinis stresas, pajègumas, eksperimentas, rezultatu palyginimas. 